\title{
Molecular Cloning and Functional Identification of Invertase Isozymes from Green Bamboo Bambusa oldhamii
}

\author{
Chang-Wen Hsieh, ${ }^{\dagger}$ Li-Ka Liu, ${ }^{\dagger}$ Sheng-Hsiung Yeh,${ }^{\dagger}$ Chi-Fu Chen,${ }^{\dagger}$ \\ HSIN-I LIN, ${ }^{\dagger}$ HSIEN-YI SUNG, ${ }^{*}, \dagger,+$ AND AI-YU WANG ${ }^{*, \dagger, *}$ \\ Institute of Microbiology and Biochemistry and Department of Biochemical Science and Technology, \\ National Taiwan University, Number 1, Section 4, Roosevelt Road, Taipei 106, Taiwan
}

\begin{abstract}
Three Boßfruct cDNAs encoding acid invertases were cloned from shoots of the green bamboo Bambusa oldhamii. On the basis of the amino acid sequences of their products and phylogenetic analyses, Boßfruct1 and Boßfruct2 were determined to encode cell wall invertases, whereas Boßfruct3 encodes a vacuolar invertase. The recombinant proteins encoded by Boßfruct2 and Boßfruct3 were produced in Pichia pastoris and purified to near homogeneity using ammonium sulfate fractionation and immobilized metal affinity chromatography. The $\mathrm{pH}$ optima, $\mathrm{pl}$ values, and substrate specificities of the isolated enzymes were consistent with those of plant cell wall or vacuolar invertases. The growth-dependent expression of Boßfruct 1 and Boßfruct 2 in the base regions of shoots underscores their roles in sucrose unloading and providing substrates for shoot growth. Its high sucrose affinity suggests that the Boßfruct2-encoded enzyme is important for maintaining the sucrose gradient between source and sink organs, while the predominant expression of Boßfruct 3 in regions of active cell differentiation and expansion suggests functions in osmoregulation and cell enlargement.
\end{abstract}

KEYWORDS: Bamboo (Bambusa oldhamii); cell-wall invertase; vacuolar invertase; cDNA cloning; recombinant invertase; gene expression

\section{INTRODUCTION}

In higher plants, sucrose is a principal product of photosynthesis, a major form of translocated carbon, and an important substrate for growth. Cleavage of sucrose, which in plants is catalyzed by either sucrose synthase (UDP-glucose:D-fructose 2- $\alpha$-D-glucosyl transferase, EC 2.4.1.13, SuS) or invertase $(\beta$ D-fructofuranoside fructohydrolase; EC 3.2.1.26), serves as a starting point for various carbohydrate metabolic pathways. The products (hexoses) of sucrose cleavage and sucrose itself can also act as direct or indirect regulators that modulate expression of diverse genes, including SuS and invertase genes (1-4), making both SuS and invertase crucial for plant development, growth, and carbon partitioning $(5,6)$.

Invertase, which irreversibly hydrolyzes sucrose into fructose and glucose, is present in plants as a group of isozymes $(7,8)$. On the basis of their $\mathrm{pH}$ optima, solubility characteristics, and subcellular localization, these isozymes have been categorized as vacuolar, cell wall-associated, and cytoplasmic invertases (also referred to as soluble acid invertase, insoluble acid invertase, and neutral/alkaline invertase, respectively). The two types of acid invertase are both glycoproteins that show optimal activity at acidic $\mathrm{pH}$, although their $\mathrm{pI}$ values differ; all known vacuolar enzymes have an acidic pI, while most of the cell wall

* To whom correspondence should be addressed. (A.-Y.W.) E-mail aywang@ntu.edu.tw. (H.-Y.S.) E-mail: sunghy@ntu.edu.tw.

Institute of Microbiology and Biochemistry.

$\doteqdot$ Department of Biochemical Science and Technology. enzymes have a basic pI. Unlike the enzyme in vacuoles or apoplasts, cytoplasmic invertases are not glycosylated and have an optimal $\mathrm{pH}$ of $7.0-7.8$ and an acidic $\mathrm{pI}$ value $(7,8)$.

The possible physiological roles of cell wall and vacuolar invertases have been analyzed in many plants. The proposed functions of cell wall invertases include regulation of phloem unloading, sucrose partitioning, cell differentiation, and plant development, as well as regulation of the responses to signals from various biotic and abiotic stresses $(5-11$ and references therein). The proposed functions of vacuolar invertases include regulation of turgor and cell enlargement, control of the sugar composition in fruits and storage organs, and involvement in the response to wounding, cold, drought, hypoxia, and gravitropism $(5-8,11$, and references therein). In contrast to acid invertases, the function of cytoplasmic invertase is unclear, but it is thought to be involved in channeling sucrose into catabolism (5).

Although studied in numerous plants, little is known about the expression and function of invertases in bamboo. Bamboo belongs to the family Poaceae (Gramineae) and is distinguished by its unique flowering habit and rapid growth. The plants typically form clumps or spread via rhizomes. As shoots emerge from buds on the rhizomes, they rapidly develop into new culms and reach their full height within a single growth season. Before the new culms are able to assimilate carbon, they depend entirely upon sucrose supplied from the mature bamboos through the rhizomes to support their rapid growth. This makes sucrose 
unloading and subsequent catabolism within shoots critical for culm growth and highlights the importance of invertases in this plant. Our aim in the present study, therefore, was to investigate the molecular and biochemical properties of invertases in growing bamboo shoots. To that end, we cloned three cDNAs encoding cell wall invertase and vacuolar invertase from shoots of green bamboo Bambusa oldhamii (synonyms, Leleba oldhami and Dendrocalamopsis oldhami), which is the most widely cultivated species in Taiwan and is valued for its shoots as a vegetable. By characterization of the heterologously expressed recombinant invertases and analysis of the levels of each invertase mRNA in shoots at different growth stages, the roles played by the three isoforms during the growth of this plant were suggested.

\section{MATERIALS AND METHODS}

Plant Materials. Fresh shoots of B. oldhamii (Munro) were harvested from a bamboo farm in Taipei, Taiwan. Etiolated shoots (15 $\mathrm{cm}$ tall on average) and three groups of green shoots (30,60, and 100 $\mathrm{cm}$ tall, on average) were collected. After the outer layers of the sheaths were removed, each shoot was divided into three parts (top, middle, and base) for separate analysis. The base was an area 5-10 $\mathrm{cm}$ above the point where the shoot joins the rhizome, the middle consisted of the developing nodes and internodes, and the top consisted of a series of overlapping sheaths surrounding the developing nodes and internodes. Unexpanded leaves and mature leaves were collected from mature bamboo plants. Each sample was immediately frozen in liquid nitrogen and stored at $-80{ }^{\circ} \mathrm{C}$ until used.

RNA Isolation. The frozen bamboo samples were ground to a fine powder in liquid nitrogen, after which the total RNA was extracted using TRIzol reagent (Invitrogen, Carlsbad, CA) according to the manufacturer's instructions. Poly (A) ${ }^{+}$RNA was purified from the total RNA with biotinylated-oligo(dT) using a PolyATract mRNA isolation system (Promega, Madison, WI).

Isolation of Partial-Length Invertase cDNA Using Reverse Transcriptase-Polymerase Chain Reaction (RT-PCR). First-strand cDNA was synthesized from poly $(\mathrm{A})^{+} \mathrm{RNA}$ isolated from etiolated bamboo shoots using an oligo-dT ${ }_{15}$ primer and RT (Superscript II, Invitrogen). The resultant cDNA was then used as a template for PCR with primers $5^{\prime}$-AAAAACTGGATGAACCATCCTAATGGT-3' and 5'-TCTTCCACCTTGAGCAAAGCTTTCAAC-3', which were designed based on conserved regions within plant acid invertase sequences. The amplified $1.4 \mathrm{~kb}$ DNA fragment was cloned into plasmid pGEM-T (Promega), and its identity was confirmed by sequencing.

Cloning Invertase cDNA by Screening a cDNA Library. The PCR-amplified 1.4 kb DNA fragment was ${ }^{32} \mathrm{P}$-labeled using a Random Prime Labeling System (Amersham Pharmacia Biotech, Buckinghamshire, United Kingdom) and used as a probe for screening a cDNA library from etiolated bamboo shoots (12). The positive plaques were isolated, subjected to in vivo excision, and amplified as phagemids for further analysis.

DNA Sequencing and Sequence Analysis. Both DNA strands were sequenced using an ABI PRISM BigDye Terminator Cycle Sequencing Ready Reaction Kit with an ABI 3730 XL DNA Analyzer (Applied Biosystems, CA). Sequence analysis, alignment of the amino acid sequences, and phylogenetic analysis were carried out using Vector NTI Suite 9 Sequence Analysis Software (Invitrogen). The cleavage site for the leader sequence was predicted by the SPScan program in the Wisconsin Package (Accelrys, Inc., San Diego, CA).

Construction of Expression Plasmids. The expression plasmids pBoIT1, pBoIT2, and pBoIT3 were constructed using similar strategies. The regions of the three Bo $\beta$ fruct cDNAs encoding the predicted mature proteins were amplified by PCR. The amplified Boßfructl DNA fragment was digested with $P s t \mathrm{I}$ and $X b a \mathrm{I}$ and then ligated with PstI$X b a I$-digested pPICZ $\alpha \mathrm{B}$ (Invitrogen) to form pBoIT1. The amplified Boßfruct 2 and Boßfruct 3 DNA fragments were digested with EcoRI and $X b a \mathrm{I}$ and respectively ligated into the EcoRI/XbaI site of plasmid $\mathrm{pPICZ} \alpha \mathrm{B}$, yielding $\mathrm{pBoIT} 2$ and $\mathrm{pBoIT} 3$.
Production and Purification of Recombinant Invertase in $\boldsymbol{P}$. pastoris. $P$. pastoris strain X-33 was transformed with $\mathrm{pBoIT} 1$, $\mathrm{pBoIT} 2$, or pBoIT3 using a Pichia EasyComp Kit (Invitrogen). Growth of the transformed cells and induction of expression with methanol were carried out according to the manufacturer's instructions. The induction times for recombinant BoIT2 and BoIT3 were 48 and $72 \mathrm{~h}$, respectively. The cultures were then centrifuged for $30 \mathrm{~min}$ at $6000 \mathrm{~g}$, after which the proteins in the centrifugal supernatant were precipitated by $80 \%$ saturation of ammonium sulfate. After centrifugation, the precipitates were dissolved in PB-7.0 (50 mM sodium phosphate, $\mathrm{pH} 7.0)$ and dialyzed against PB-7.0 containing $0.3 \mathrm{M} \mathrm{NaCl}$. The resultant enzyme solution was mixed with cobalt-based immobilized metal affinity chromatography (IMAC) resin (BD TALON Resin, BD Biosciences Clontech, Palo Alto, CA) and incubated for $30 \mathrm{~min}$ at $4{ }^{\circ} \mathrm{C}$. The enzyme-resin mixture was then packed into a column, washed with PB-7.0 containing $0.3 \mathrm{M} \mathrm{NaCl}$ and $10 \mathrm{mM}$ imidazole, and then eluted with PB-7.0 containing $0.3 \mathrm{M} \mathrm{NaCl}$ and $150 \mathrm{mM}$ imidazole. Fractions containing invertase activity were collected.

Enzyme Assay and Protein Analytic Methods. The invertase activity was assayed at pH 5.0 as described by Sung and Huang (13). The protein concentration was determined using the protein-dye binding method (14), with bovine serum albumin serving as the standard protein. For deglycosylation of the recombinant invertase, $10 \mu \mathrm{g}$ of the purified enzymes (in PB-7.0) was incubated with 10 units of N-glycosidase F (PNGase F, Roche Applied Science, Mannheim, Germany) at $37{ }^{\circ} \mathrm{C}$ for $16 \mathrm{~h}$.

Proteins were separated by $12.5 \%$ sodium dodecyl sulfate-polyacrylamide gel electrophoresis (SDS-PAGE) according to the method of Laemmli (15), and the proteins on the gels were stained with Coomassie Blue R-250 or silver nitrate or were transferred onto PVDF membranes (Millipore, Bedford, MA) for immunodetection using an anti-(His) $)_{6}$ antibody (Amersham Pharmacia Biotech).

Semiquantitative RT-PCR. Reverse transcription reactions were carried out using total RNA isolated from the various bamboo samples collected. The resultant cDNAs were then used as templates for PCR with gene-specific primers to amplify each Boßfruct cDNA. The sequences of the gene-specific primer pairs were as follows: Boßfruct1, 5'-GAAGAGGATCTTCCTTCGTG-3' (forward; nucleotides 18801899) and 5'-CCTAGAGGCATACAAATTGGC-3' (reverse; nucleotides 2028-2048); Boßfruct2, 5'-CACCACTCTGCTAACTCAT-3' (forward; nucleotides 1764-1782) and 5'-ACAGTGCGAAATTAGCACC-3' (reverse; nucleotides 1952-1970); and Boßfruct3, 5'CCAAGCCTACATGGCTTAA-3' (forward; nucleotides 2017-2035) and 5'-TGCTTGCATCATGGCATCT-3' (reverse; nucleotides 21712189). An actin cDNA fragment was also amplified as an internal control using primers 5'-TGGCATCACACCTTCTACAA-3' (forward) and 5'-ACCTGGATCTTCATGCTGCT-3' (reverse), which were designed from the conserved regions of monocot actin sequences. The amplified cDNA fragments were sequenced to confirm their specificity; moreover, for each cDNA, the linearity of the amplification was confirmed by carrying out the PCR for different numbers of cycles.

\section{RESULTS}

Cloning and Characterization of Invertase cDNA from Bamboo Shoots. A partial-length cDNA clone, presumably encoding invertase, was obtained by RT-PCR using a set of primers designed from the conserved regions of plant invertase sequences and poly $(\mathrm{A})^{+} \mathrm{RNA}$ isolated from bamboo shoots. The deduced amino acid sequence was highly homologous to the corresponding regions of acid invertases from other plants (data not shown), so the cDNA was used as a hybridization probe to screen a bamboo shoot cDNA library, and nine potential clones were selected and subjected to further analysis. Nucleotide sequence analysis revealed that all nine clones contained a $5^{\prime}$ UTR, an open reading frame, a 3'-UTR, and a poly(A) tail and could be divided into three distinct types: Bo $\beta$ fruct1, Bo $\beta$ fruct 2 , and Boßfruct3. The characteristics of the three cDNAs and their deduced amino acid sequences are summarized in Table 1 . The amino acid sequences deduced from Bo $\beta$ fruct 1 and Bo $\beta$ fruct 2 
Table 1. Summary of the Boßfruct cDNA Sequences ${ }^{a}$

\begin{tabular}{lccc}
\hline & Boßfruct1 & Boßfruct2 & Boßfruct3 \\
\hline & cDNA & & \\
5'-UTR (bp) & 113 & 24 & 58 \\
ORF (bp) & 1761 & 1731 & 1977 \\
3'-UTR (bp) & 274 & 270 & 225 \\
& protein & & \\
amino acid (no. of residues) & 586 & 576 & 658 \\
molecular mass (kDa) & 65.6 & 64.4 & 71.9 \\
pl & 8.87 & 7.25 & 5.69 \\
leader sequence (no. of & 22 & 22 & 57 \\
$\quad$ residues) & 3 & 3 & \\
glycosylation site (no.) & 63.2 & 62.1 & 66.3 \\
molecular mass of mature & & & \\
$\quad$ protein (kDa) & 8.66 & 7.23 & 5.60 \\
pl of mature protein & & & \\
& &
\end{tabular}

a The accession numbers for Boßfruct1, Boßfruct2, and Boßfruct3 are DQ267823, DQ267824, and DQ267825, respectively.

were $81 \%$ identical but showed lower identity to the sequence deduced from Boßfruct3 (52 and 51\%, respectively). BLAST analysis revealed that the predicted proteins encoded by Boßfruct1, Boßfruct2, and Boßfruc 3 had the highest identity to rice cell wall invertase OsCIN2 (accession number AY578159, $85.3 \%$ ), rice cell wall invertase OsCIN1 (AB073749, 83.8\%), and rice vacuolar invertase INV3 (AF276704, 78.3\%), respectively.

Figure 1 shows the alignment of the amino acid sequences. All three sequences contain the typical motifs of plant acid invertases, including a $\beta$-fructosidase motif "NW[M/I]NDPN[G/A]", a putative catalytic domain "WEC[V/I/P]D", and a conserved "S[V/I]VESF" sequence $(7,8,16)$. Moreover, the three sequences all contain leader sequences in their $\mathrm{N}$ terminus, as are found in all plant acid invertases $(7,8)$. Although plant fructan-metabolizing fructosyltransferases also share motifs conserved among acid invertases and both are highly homologous to one another $(17,18)$, acid invertases can be differentiated from fructan-metabolizing enzymes based on an amino acid triplet, WMN or WIN, in the $\beta$-fructosidase motif $(16,19)$. The presence of WIN in the amino acid sequences deduced from Boßfruct 1 and Boßfruct2 (amino acid residues 61-63 and 6062 , respectively) and $\mathrm{WMN}$ in the sequence deduced from Boßfruct3 (112-114) (Figure 1) confirms that the three genes encode acid invertases and not fructan-metabolizing enzymes.

As shown in Figure 2, the proteins encoded by Boßfruct 1 and Boßfruct 2 have a closer evolutionary relationship to cell wall invertases than to vacuolar invertases, whereas the protein encoded by Boßfruct 3 appears to belong to the vacuolar invertase family. Several features in the three Boßfruct-encoded sequences also support this classification: (i) The fourth residue of the conserved catalytic domain WEC[V/I/P]D in the Boßfruct1and Boßfruct2-encoded proteins is proline, which is characteristic of cell wall invertases, and the corresponding amino acid residue in the Boßfruct 3 -encoded protein is isoleucine, which has been seen in some vacuolar invertases (7). (ii) The predicted leader sequences for the Boßfruct1-, Boßfruct2-, and Boßfruc3encoded proteins are 22, 22, and 57 amino acids in length, which is consistent with that the leader sequences of vacuolar invertases are longer than those of cell wall invertases $(7,8,19)$. (iii) The $\mathrm{pI}$ values for the mature proteins of the three isoforms were calculated to be $8.66,7.23$, and 5.60, respectively, which are consistent with the previous observations that cell wall invertases have basic $\mathrm{pI}$ values and vacuolar invertases have acidic ones $(7,8,11)$.

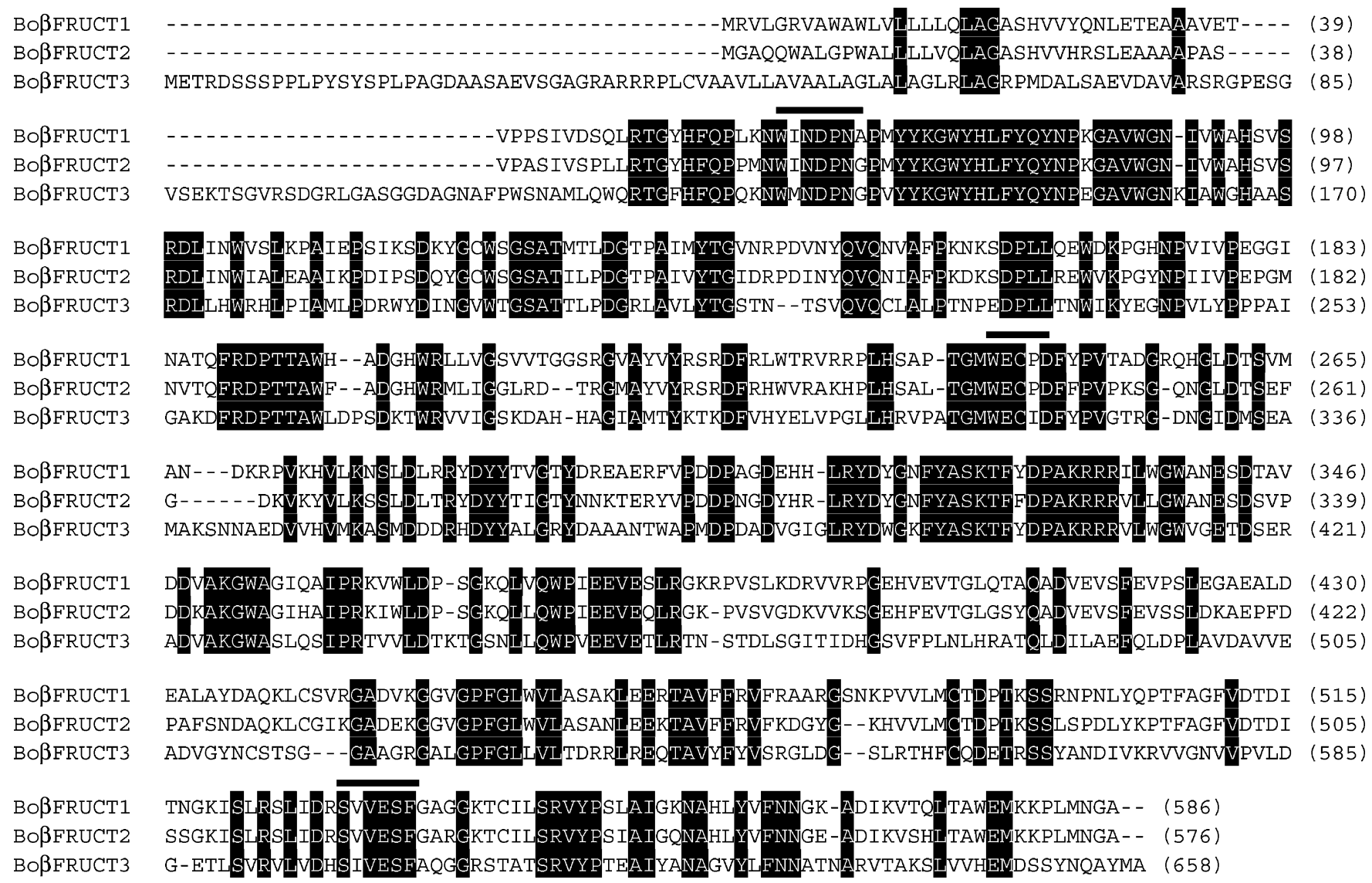

Figure 1. Alignment of the deduced amino acid sequences derived from bamboo Boßfruct cDNAs. Identical residues are shown on a black background. The characteristic conserved elements of acid invertases are indicated by lines above the sequences. 


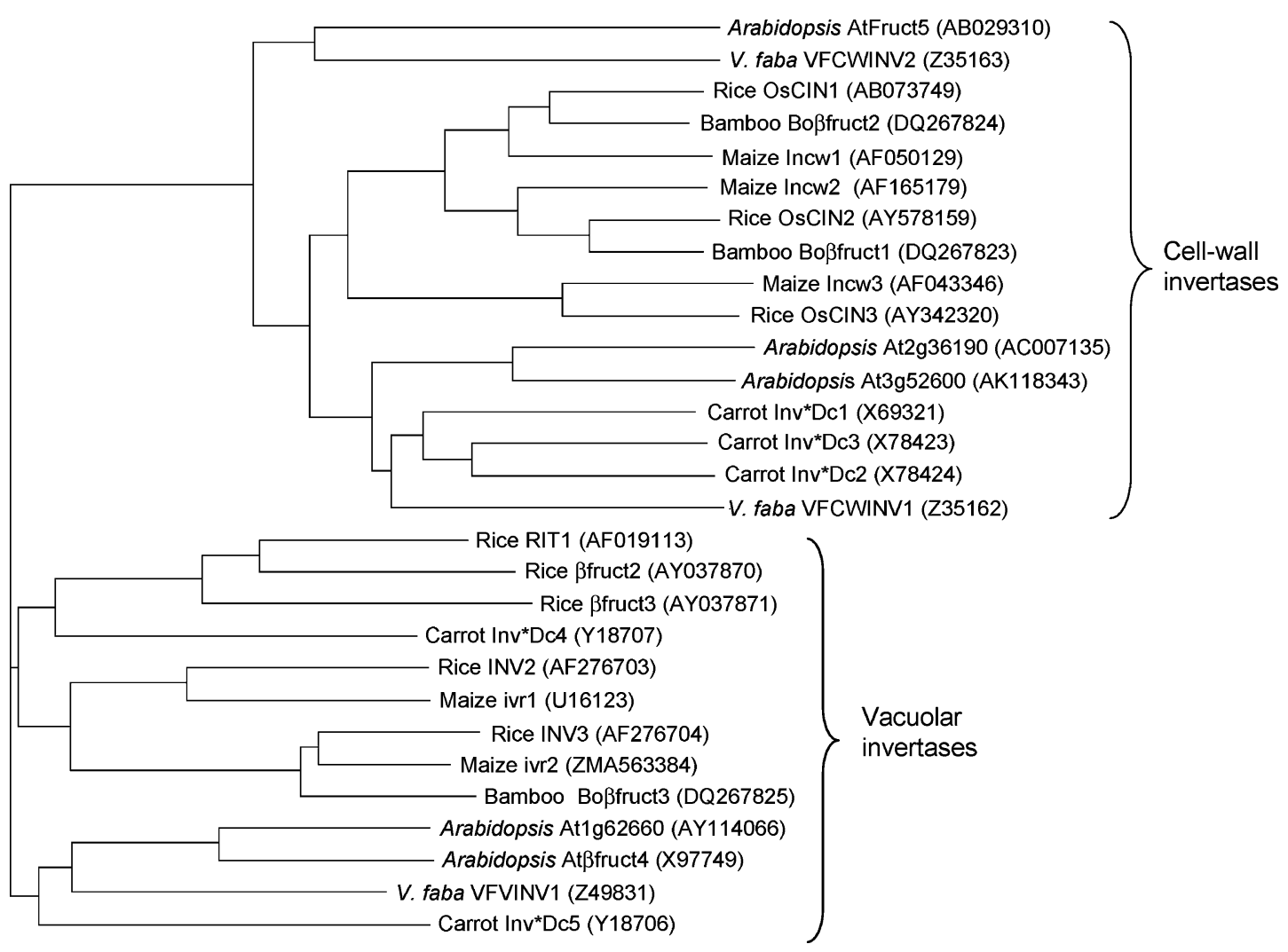

Figure 2. Phylogram of the amino acid sequences of invertases from various plants.

Expression of the Boßfruct-Encoded Proteins in Yeast. To further characterize the proteins encoded by the three Boßfruct genes, the cDNA sequences encoding the putative mature protein regions were cloned into a secreted and His-tag fusion expression vector (pPICZ $\alpha \mathrm{B})$, which was then used to transform $P$. pastoris. Strains harboring Boßfruct1, Boßfruct2, and Bo $\beta$ fruct 3 (YIT1, YIT2, and YIT3, respectively) were grown at $30^{\circ} \mathrm{C}$ in the presence of methanol. Acid invertase activity and $77 \mathrm{kDa}$ His-tagged proteins were detected in the growth medium of strains YIT2 and YIT3 (Figure 3A,B). However, the invertase activity in the growth medium of strain YIT1 was barely detected and the His-tagged proteins were undetectable. It remains to be determined whether the expression level of recombinant Bo $\beta$ fruct 1 -encoded proteins was low or the proteins were unstable under our experimental conditions.

The recombinant Boßfruct2- and Boßfruct 3 -encoded proteins (designated rBoIT2 and rBoIT3, respectively) were purified to near homogeneity from the growth media of methanol-induced strains YIT2 and YIT3, respectively, using ammonium sulfate fractionation and cobalt-based IMAC (Figure 4). The specific activity of the purified rBoIT3 was 1.9 times that of rBoIT2 (Table 2).

Biochemical Properties of the Recombinant Invertases. The molecular masses of rBoIT2 and rBoIT3 were estimated to be 70.1 and $72.6 \mathrm{kDa}$, respectively, using gel filtration chromatography, which is very close to those estimated by SDSPAGE (77.5 kDa for both, Figure 4), suggesting that the native form of the two enzymes is a monomer. After PNGase F treatment, the resultant deglycosylated forms exhibited the electrophoretic mobility of a 68.2 kDa protein (Figure 4), which is very close to the calculated molecular masses for the c-myc and His tag-fused recombinant enzymes (62.5 and $64.5 \mathrm{kDa}$, respectively). The pI values estimated by IEF were 9.2 for rBoIT2 and 6.5 for rBoIT3 (data not shown). Although these values are higher than the calculated $\mathrm{pI}$ values for the nongly- cosylated recombinant enzymes, they are consistent with the fact that plant cell wall invertases have basic pI values, while vacuolar invertases have acidic ones.

The optimum reaction temperatures were found to be $60{ }^{\circ} \mathrm{C}$ for rBoIT2 and $50{ }^{\circ} \mathrm{C}$ for rBoIT3. Both enzymes had similar thermostabilities. They were stable within the temperature range of $0-30{ }^{\circ} \mathrm{C}$, and their activities were completely lost at $50{ }^{\circ} \mathrm{C}$ (data not shown). The $\mathrm{pH}$ stability profiles of the two recombinant enzymes are also similar. Both were stable at acidic $\mathrm{pH}$ (Figure 5A). rBoIT2 had a pH optimum of 3.0, while rBoIT3 showed the highest activity within a $\mathrm{pH}$ range of 4-5 (Figure 5B). At pH 2.0, rBoIT2 still retained 90\% activity, but rBoIT3 exhibited no detectable activity. Their affinities for sucrose differ substantially: the apparent $K_{\mathrm{m}}$ values of rBoIT2 and rBoIT3 for sucrose were 0.42 and $22.9 \mathrm{mM}$, respectively.

In addition to acting on sucrose, rBoIT2 and rBoIT3 also hydrolyzed raffinose, exhibiting activities that were 92.1 and $24.6 \%$ of that toward sucrose, respectively. No hydrolytic activity was detected with maltose, lactose, or cellobiose. This substrate specificity is consistent with that for $\beta$-fructofuranosidases.

Table 3 shows the effects of metal ions on the activities of rBoIT2 and rBoIT3. The activities of both enzymes were inhibited by $\mathrm{HgCl}_{2}$, which is known to act as a sulfhydryl inhibitor of plant invertases $(8)$. rBoIT2 was activated by $\mathrm{Ca}^{2+}$ and $\mathrm{Co}^{2+}$ and was inhibited by the other ions tested. The activity of rBoIT3 was not affected by $\mathrm{K}^{+}$and $\mathrm{Ca}^{2+}$ significantly but was inhibited by the other ions tested. The enzyme was more sensitive to $\mathrm{Cu}^{2+}, \mathrm{Fe}^{2+}, \mathrm{Hg}^{2+}, \mathrm{Mn}^{2+}$, and $\mathrm{Zn}^{2+}$ than was rBoIT2.

Expression of Boßfruct Genes in the Growing Bamboo and Leaves. The expression of the three Boßfruct genes in growing bamboo shoots and leaves was examined using semiquantitative RT-PCR (Figure 6). In shoots, levels of Boßfruct l mRNA were higher in the base region than the other two regions and increased as the shoots grew. Levels of Bo $\beta$ fruct 2 mRNA in different regions of the same shoot did 


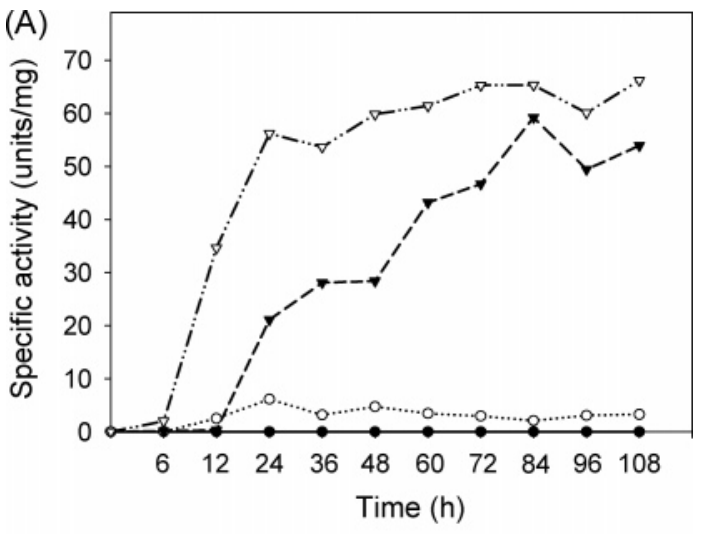

(B)

(C)

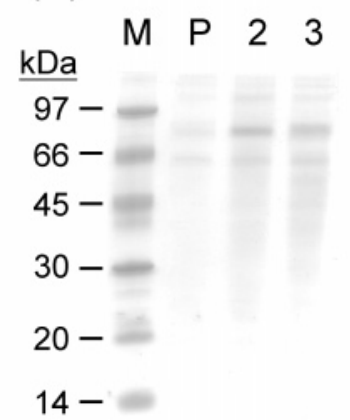

$P 23$

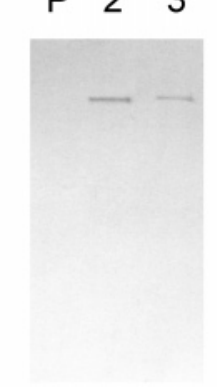

Figure 3. Expression of recombinant invertases in $P$. pastoris. (A) Strains YIT1 $(O)$, YIT2 $(\boldsymbol{\nabla})$, and YIT3 $(\nabla)$, which, respectively, harbored Boßfruct1, Boßfruct2, and Boßfruct3, or cells transformed with empty $\mathrm{pPICZ} \alpha \mathrm{B}$ vector $(\bullet)$, were grown in media without methanol at $30^{\circ} \mathrm{C}$ until the $A_{600}$ values reached 1.0, after which expression of recombinant proteins was induced by adding methanol to the cultures. Samples were collected at various times after induction. Proteins secreted into the culture medium and those present in the cellular fraction were assayed for invertase activity at $\mathrm{pH}$ 5.0 (A). The secreted proteins of cells harvested after $48 \mathrm{~h}$ of induction were separated on $10 \%$ SDS-polyacrylamide gels, which were then stained with Coomassie blue R-250 (B) or transferred onto a PVDF membrane and immunodetected with an anti-(His) ${ }_{6}$ antibody $(\mathbf{C})$. M, molecular mass markers; $\mathrm{P}$, cells transformed with $\mathrm{PPICZ} \alpha \mathrm{B} ; 2$, strain YIT2; and 3, strain YIT3.

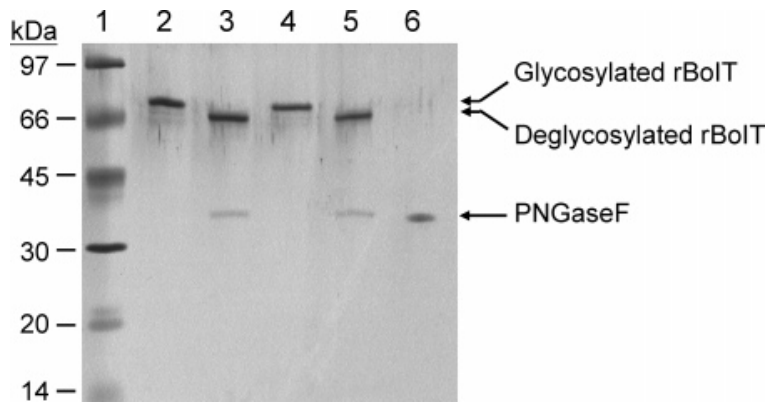

Figure 4. Analysis of purified and deglycosylated recombinant invertases. Purified rBolT2 and rBolT3 were incubated with PNGase $F$ for $16 \mathrm{~h}$ at 37 ${ }^{\circ} \mathrm{C}$ and then separated on $12.5 \%$ SDS-PAGE. The resolved proteins were stained with silver nitrate: lane 1, molecular mass markers; lanes 2 and 4, purified rBolT2 and rBolT3; lanes 3 and 5, purified rBolT2 and rBolT3 treated with PNGase F; and lane 6, PNGase F.

not show the distinct differences seen with Boßfructl, but the accumulation of Bo $\beta$ fruct 2 mRNA in the base region was also growth-dependent. The highest level of Boßfruct 2 mRNA was seen in $100 \mathrm{~cm}$ green shoots. Boßfruct 2 mRNA was also abundant in leaves, especially in source leaves, whereas there was little expression of Boßfructl in both sink and source leaves. In contrast to Boßfruct 1 and Boßfruct2, there was only a low level of Boßfruct 3 mRNA in the base region of shoots; levels were highest in the middle and the top regions of $60 \mathrm{~cm}$ green shoots. The transcript of Boßfruct 3 was barely detectable in leaves.

\section{DISCUSSION}

We have isolated three cDNA clones encoding acid invertases from bamboo shoots. On the basis of their amino acid sequences and phylogenetic analysis, Boßfructl and Boßfruct 2 were determined to be cell wall invertase genes, while Boßfruct 3 was a vacuolar invertase gene. The proteins encoded by Bo $\beta$ fruct 2 and Boßfruct 3 were successfully expressed and purified from $P$. pastoris. The two recombinant enzymes (rBoIT2 and rBoIT3) were both stable at acidic $\mathrm{pH}$ and had acidic optimal $\mathrm{pH}$ values, which is consistent with the acidic environment of apoplasts and vacuoles. Moreover, the finding that the $\mathrm{pH}$ optimum for rBoIT2 was lower than that for rBoIT3 is consistent with earlier observations that in some plants cell wall invertases have lower $\mathrm{pH}$ optima than vacuolar invertases from the same species $(20-$ 22). This difference in $\mathrm{pH}$ optima has been attributed to a single amino acid substitution in the catalytic domain WEC[V/I/P]D: Cell wall invertases contain a proline residue, while vacuolar invertases contain valine or isoleucine (23). Substituting the proline residue in the catalytic domain of cell wall invertase with a valine shifts the $\mathrm{pH}$ optimum toward more basic values and decreases the rate of raffinose cleavage (23). The difference in the rates on raffinose cleavage exhibited by different invertases was also observed in the present study; i.e., rBoIT2 (cell wall enzyme) showed a greater activity toward raffinose than rBoIT3 (vacuolar enzyme). This is consistent with the result of Goetz and Roitsch (23) who proposed that the proline and valine/isoleucine residues play a key role in determining the substrate specificity of the two enzymes. However, involvement of other amino acid residues cannot be excluded.

In an earlier study, two soluble acid invertases (type I and type II) and two cell wall isoforms (type III and type IV) were purified from green bamboo shoots (24). The $K_{\mathrm{m}}$ value of rBoIT3 was nearly identical to the type II enzyme $(22.5 \mathrm{mM})$ but higher than the type I enzyme $(7.9 \mathrm{mM})$ from green bamboo shoots and other soluble acid invertases from maize endosperms ( 2 and $10.5 \mathrm{mM}$ for invertases I and II, respectively, 25), wheat coleoptiles (3.5 mM, 26), barley elongating stem tissue (12.0 $\mathrm{mM}, 20)$, potato leaves and tubers $(2.4$ and $7.9 \mathrm{mM}$, respectively, 27), rice grains (0.94 and $12.1 \mathrm{mM}$ for IT4 and IT5, respectively, 28), Arabidopsis leaves (5, 12, and $5 \mathrm{mM}$ for INV1, INV2, and INV3, respectively, 22), pear fruit (3.33 and 4.58 $\mathrm{mM}$ for AIV I and AIV II, respectively, 29), and suspensioncultured cells of a different bamboo species (Bambusa edulis) (3.7 $\mathrm{mM}, 30$ ). The $K_{\mathrm{m}}$ value of rBoIT2 was lower than the cell wall invertases from green bamboo shoots $(1.3 \mathrm{mM}$ for type IV isoform, 24) and other plants such as maize endosperm (8 $\mathrm{mM}, 25)$, sugar beet seedlings (1.33 mM, 31), Lilium pollen (0.98 mM, 32), wheat coleoptiles (1.7 mM, 26), suspensioncultured cells of sugar beet $(0.56$ and $4.2 \mathrm{mM}$ for saline-released and EDTA-released enzymes, 33), barley elongating stem tissue $(5.0 \mathrm{mM}, 20)$, and rice grains $(5.39 \mathrm{mM}, 13)$. It is noteworthy that rBoIT2 had the highest affinity for sucrose among known cell wall invertases. This characteristic could be related to its physiological function within this remarkable plant, which exhibits a high growth rate. The average elongation rate of bamboo culms is $9.7 \mathrm{~cm} /$ day for $B$. oldhamii (34) and can be over $100 \mathrm{~cm} /$ day for Phyllostachys edulis (35). To support the 
Table 2. Purification of the Recombinant Invertases rBolT2 and rBolT3 from Transformed P. pastoris ${ }^{a}$

\begin{tabular}{|c|c|c|c|c|c|c|}
\hline purification step & enzyme & $\begin{array}{l}\text { total activity } \\
\left.\quad \text { (units }^{b}\right)\end{array}$ & $\begin{array}{l}\text { total protein } \\
(\mathrm{mg})\end{array}$ & $\begin{array}{l}\text { specific activity } \\
\text { (units } / \mathrm{mg} \text { ) }\end{array}$ & $\begin{array}{c}\text { yield } \\
(\%)\end{array}$ & $\begin{array}{l}\text { purification } \\
\text { (fold) }\end{array}$ \\
\hline \multirow{6}{*}{$\begin{array}{l}\text { centrifugal supernatant } \\
\text { of the culture } \\
\text { ammonium sulfate } \\
\text { fractionation } \\
\text { Co-IMAC }\end{array}$} & rBolT2 & 9616.4 & 164.77 & 58.4 & 100 & 1.0 \\
\hline & rBolT3 & 10936.4 & 157.26 & 69.5 & 100 & 1.0 \\
\hline & rBolT2 & 3942.7 & 82.25 & 47.9 & 41 & 0.82 \\
\hline & rBolT3 & 3385.3 & 30.61 & 110.6 & 31 & 1.6 \\
\hline & rBolT2 & 1538.6 & 1.74 & 884.3 & 16 & 15.1 \\
\hline & rBolT3 & 2542.0 & 1.50 & 1694.5 & 23 & 24.3 \\
\hline
\end{tabular}

${ }^{a}$ The data were obtained from the centrifugal supernatant of a $1 \mathrm{~L}$ culture of methanol-induced $P$. pastoris harboring Bo $\beta$ fruct2 or Bo $\beta$ fruct3. ${ }^{b}$ One unit of invertase was defined as the amount of enzyme that catalyzed the formation of $1 \mu \mathrm{mol}$ of reducing sugar from sucrose per minute at $37^{\circ} \mathrm{C}$ and $\mathrm{pH} 5.0$.
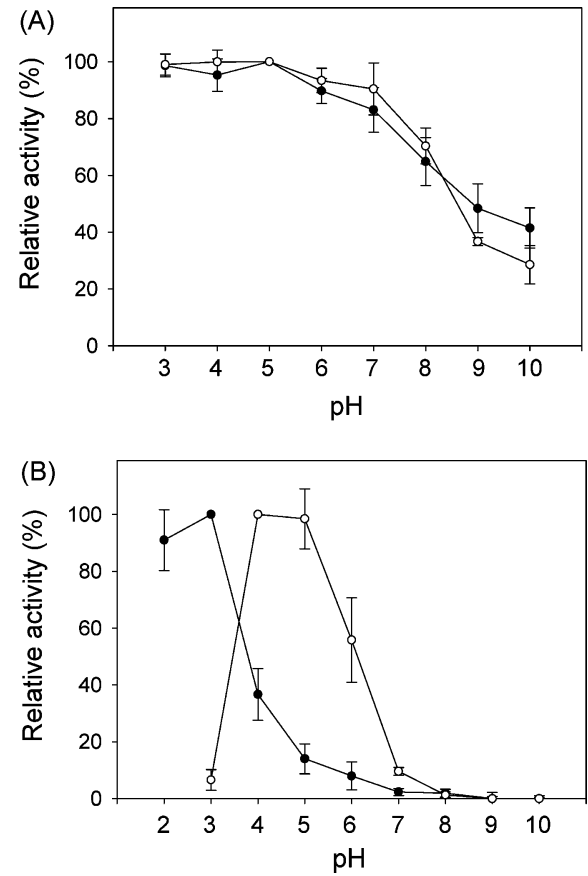

Figure 5. Effects of $\mathrm{pH}$ on the activity of recombinant invertase. (A) $\mathrm{pH}$ stability profile: purified rBolT2 $(\bullet)$ and rBolT3 $(O)$ were incubated at various $\mathrm{pH}$ values for $30 \mathrm{~min}$, after which the residual invertase activity was determined at pH 5.0. (B) pH optima: purified rBolT2 (O) and rBolT3 $(\mathrm{O})$ were assayed at various $\mathrm{pH}$ values.

Table 3. Effect of Metal lons on the Activity of Recombinant Invertases

\begin{tabular}{|c|c|c|c|c|c|}
\hline \multirow{2}{*}{$\begin{array}{l}\text { addition } \\
(5 \mathrm{mM})\end{array}$} & \multicolumn{2}{|c|}{ relative activity (\%) } & \multirow{2}{*}{$\begin{array}{l}\text { addition } \\
(5 \mathrm{mM})\end{array}$} & \multicolumn{2}{|c|}{ relative activity (\%) } \\
\hline & rBolT2 & rBolT3 & & rBolT2 & rBolT3 \\
\hline none & 100 & 100 & $\mathrm{FeCl}_{2}$ & 41.5 & 3.7 \\
\hline $\mathrm{KCl}$ & 87.4 & 95.1 & $\mathrm{HgCl}_{2}$ & 29.5 & 2.1 \\
\hline LiCl & 76.6 & 85.9 & $\mathrm{MgCl}_{2}$ & 90.9 & 88.9 \\
\hline $\mathrm{CaCl}_{2}$ & 108.7 & 96.7 & $\mathrm{MnCl}_{2}$ & 84.5 & 48.6 \\
\hline $\mathrm{CoCl}_{2}$ & 129.4 & 11.3 & $\mathrm{ZnCl}_{2}$ & 82.1 & 16.2 \\
\hline $\mathrm{CuCl}_{2}$ & 32.8 & 0.6 & & & \\
\hline
\end{tabular}

rapid growth, effective translocation of sucrose from source organs of mature bamboo to shoots must be required. The presence of high sucrose affinity invertases that readily bind sucrose within the apoplasts of sink cells would be expected to facilitate such translocation by helping to sustain a sucrose gradient between the source and the sink organs.

The above postulation that Boßfruct2-encoded invertase is involved in sucrose unloading is further supported by the growth-dependent expression pattern of Boßfruct 2 in the base regions of the shoots. The base of the shoot is the area just above the point where the shoot joins the rhizome and is the
(A) $\frac{E}{b m t} \frac{G 30}{b m t} \frac{G 60}{b m t} \frac{G 100}{b m t}$ SL ML
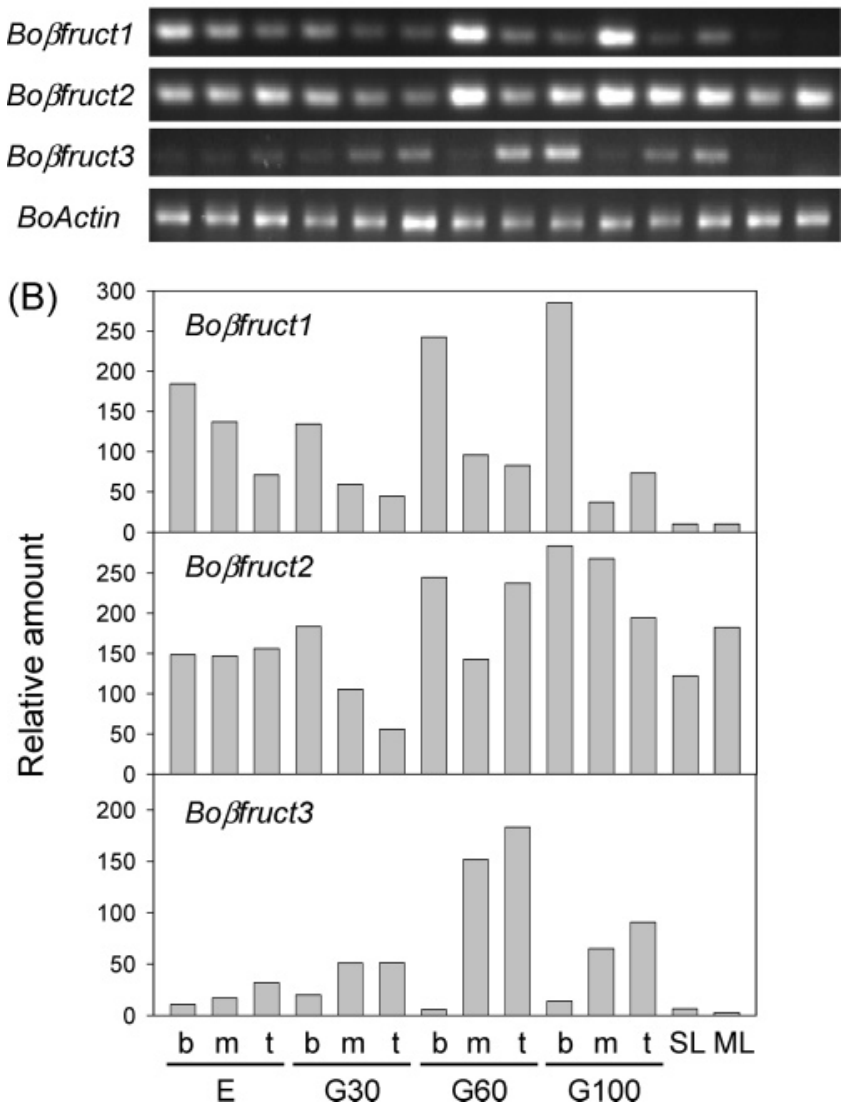

Figure 6. Expression of Boßfruct genes in bamboo. Total RNA was isolated from $15 \mathrm{~cm}$ etiolated shoots (E), $30 \mathrm{~cm}$ green shoots (G30), 60 $\mathrm{cm}$ green shoots (G60), $100 \mathrm{~cm}$ green shoots (G100), sink leaves (unexpanded leaves, SL), and source leaves (mature leaves, ML). Each shoot was divided into three parts: the base $(b)$, middle $(m)$, and top (t). The relative abundance of mRNA was analyzed by RT-PCR using specific primers for each gene. Amplification of actin transcript (BoActin) was carried out in parallel as an internal control. (A) RT-PCR products analyzed by agarose gel electrophoresis. (B) The densities of the CDNA bands in panel A were quantitated using an image analyzer and normalized to the actin cDNA level. The figures show a representative example from three independent experiments having similar results.

site at which sucrose unloading occurs. Furthermore, the highest levels of Boßfruct $2 \mathrm{mRNA}$ were found in the base of $100 \mathrm{~cm}$ green shoots, which is the stage at which the rates of culm elongation are higher (34). Similarly, the level of Boßfructl mRNA in the base region paralleled the growth of shoots, which is indicative of the importance of both of these cell wall invertases in sucrose translocation. However, the two isoforms 
likely have different functions in different tissues, as the relative abundance of their mRNAs differed in the various shoot tissues and in the leaves. In contrast to the predominant expression of Boßfructl in the base of the shoot, the expression of Bo $\beta$ fruct 3 was higher in the top and middle regions of the shoots, where rapid cell differentiation and expansion are ongoing. The pattern of Boßfruct 3 expression is consistent with the involvement of vacuolar invertases in osmoregulation and cell enlargement.

While our results show a close correlation between the abundance of the three invertase mRNAs and bamboo growth, how the gene expression and enzyme activity are regulated and whether these enzymes play regulatory roles in sugar-mediated modulation of gene expression remain unknown. We will focus on these important issues in the future with the aim of gaining additional insight into the growth of this remarkable plant.

\section{LITERATURE CITED}

(1) Koch, K. E. Carbohydrate-modulated gene expression in plants. Annu. Rev. Plant Physiol. Plant Mol. Biol. 1996, 47, 509-540.

(2) Roitsch, T. Source-sink regulation by sugar and stress. Curr. Opin. Plant Biol. 1999, 2, 198-206.

(3) Smeekens, S. Sugar-induced signal transduction in plants. Annu. Rev. Plant Physiol. Plant Mol. Biol. 2000, 51, 49-81.

(4) Rolland, F.; Moore, B.; Sheen, J. Sugar sensing and signaling in plants. Plant Cell 2002, Supplement, S185-S205.

(5) Sturm, A.; Tang, G.-Q. The sucrose-cleaving enzymes of plants are crucial for development, growth and carbon partitioning. Trends Plant Sci. 1999, 4, 401-407.

(6) Koch, K. Sucrose metabolism: regulatory mechanisms and pivotal roles in sugar sensing and plant development. Curr. Opin. Plant Biol. 2004, 7, 235-246.

(7) Tymowska-Lalanne, Z.; Kreis, M. The plant invertases: Physiology, biochemistry and molecular biology. In Advances in Botanical Research; Callow, J. A., Ed.; Academic Press: New York, 1998; Vol. 28, pp 71-117.

(8) Sturm, A. Invertase. Primary structures, functions, and roles in plant development and sucrose partitioning. Plant Physiol. 1999, $121,1-8$

(9) Roitsch, T.; Balibrea, M. E.; Hofmann, M.; Proels, R.; Sinha, A. K. Extracellular invertase: Key metabolic enzyme and PR protein. J. Exp. Bot. 2003, 54, 513-524.

(10) Sherson, S. M.; Alford, H. L.; Forbes, S. M.; Wallace, G.; Smith, S. M. Roles of cell-wall invertase and monosaccharide transporters in the growth and development of Arabidopsis. J. Exp. Bot. 2003, 54, 525-531.

(11) Roitsch, T.; Gonzalez, M.-C. Function and regulation of plant invertases: Sweet sensations. Trends Plant Sci. 2004, 9, 606613.

(12) Chiu, W.-B.; Lin, C.-H.; Chang, C.-J.; Hsieh, M.-H.; Wang, A.Y. Molecular characterization and expression of four cDNAs encoding sucrose synthase from green bamboo Bambusa oldhamii. New Phytol. 2006, 170, 53-63.

(13) Sung, H.-Y.; Huang, W.-C. Purification and characterization of cell-wall-bound invertase from rice (Oryza sativa) grains. Biotechnol. Appl. Biochem. 1994, 19, 75-83.

(14) Bradford, M. M. A rapid and sensitive method for the quantitation of microgram quantities of protein utilizing the principle of protein-dye binding. Anal. Biochem. 1976, 72, 248-254.

(15) Laemmli, U. K. Cleavage of structural proteins during assembly of the head of bacteriophage T4. Nature 1970, 227, 680-685.

(16) Van den Ende, W.; Michiels, A.; Roy, K. L.; Van Laere, A. Cloning of a vacuolar invertase from Belgian endive leaves (Cichorium intybus). Physiol. Plant. 2002, 115, 504-512.

(17) Vijn, I.; Smeekens, S. Fructan: More than a reserve carbohydrate? Plant Physiol. 1999, 120, 351-360.
(18) Ritsema, T.; Smeekens, S. C. M. Engineering fructan metabolism in plants. J. Plant Physiol. 2003, 160, 811-820.

(19) Gallagher, J. A.; Cairns, A. J.; Pollock, C. J. Cloning and characterization of a putative fructosyltransferase and two putative invertase genes from the temperate grass Lolium temulentum L. J. Exp. Bot. 2004, 55, 557-569.

(20) Karuppiah, N.; Vadlamudi, B.; Kaufman, P. B. Purification and characterization of soluble (cytosolic) and bound (cell wall) isoforms of invertases in barley (Hordeum vulgare) elongating stem tissue. Plant Physiol. 1989, 91, 993-998.

(21) Unger, C.; Hardegger, M.; Lienhard, S.; Sturm, A. cDNA cloning of carrot (Daucus carota) soluble acid $\beta$-fructofuranosidase and comparison with the cell wall isozyme. Plant Physiol. 1994, 104, $1351-1357$.

(22) Tang, X.; Ruffner, H. P.; Scholes, J. D.; Rolfe, S. A. Purification and characterization of soluble invertases from leaves of Arabidopsis thaliana. Planta 1996, 198, 17-23.

(23) Goetz, M.; Roitsch, T. The different $\mathrm{pH}$ optima and substrate specificities of extracellular and vacuolar invertases from plants are determined by a single amino acid substitution. Plant J. 1999, 20, 707-71.

(24) Cheng, J.-F.; Mitsuya, N.; Juang, R.-H.; Sung, H.-Y. Purification and characterization of invertase isozymes from bamboo shoots. Biochem. Int. 1990, 21, 497-506.

(25) Jaynes, T.-A.; Nelson, O. E. Invertase activity in normal and mutant maize endosperms during development. Plant Physiol. 1971, 47, 623-628.

(26) Krishnan, H. B.; Blanchette, J. T.; Okita, T. W. Wheat invertases. Characterization of cell wall-bound and soluble forms. Plant Physiol. 1985, 78, 241-245.

(27) Burch, L. R.; Davies, H. V.; Cuthbert, E. M.; Macgray, G. C.; Hedley, P.; Waugh, R. Purification of soluble invertase from potato. Phytochemistry 1992, 31, 1901-1904.

(28) Charng, Y.-Y.; Juang, R.-H.; Su, J.-C.; Sung, H.-Y. Partial purification and characterization of invertase isozymes from rice grains (Oryza sativa). Biochem. Mol. Biol. Int. 1994, 33, 607615.

(29) Hashizume, H.; Tanase, K.; Shiratake, K.; Mori, H.; Yamaki, S. Purification and characterization of two soluble acid invertase isozymes from Japanese pear fruit. Phytochemistry 2003, 63, $125-129$.

(30) Liu, C.-C.; Huang, L.-C.; Chang, C.-T.; Sung, H.-Y. Purification and characterization of soluble invertases from suspensioncultured bamboo (Bambusa edulis) cells. Food Chem. 2006, 96, 621-631.

(31) Masuda, H.; Sugawara, S. Purification and some properties of cell wall-bound invertases from sugar beet seedlings and aged slices of mature roots. Plant Physiol. 1980, 66, 93-96.

(32) Singh, M. B.; Knox, R. B. Invertases of Lilium pollen. Characterization and activity during in vitro germination. Plant Physiol. 1984, 74, 510-515.

(33) Masuda, H.; Takahashi, T.; Sugawara, S. Acid and alkaline invertases in suspension cultures of sugar beet cells. Plant Physiol. 1988, 86, 312-317.

(34) Lin, W. C. Studies on the growth of bamboo species in Taiwan. Bull. Taiwan For. Res. Inst. 1958, 54.

(35) Ueda, K. Studies on the physiology of bamboo; with reference to practical application. Forests Bulletin; Kyoto University: Kyoto, Japan, 1960; Vol. 30.

Received for review November 1,2005 . Revised manuscript received February 25, 2006. Accepted February 28, 2006. This work was supported by grants from the National Science Council, the Republic of China (Taiwan).

JF052711S 